\title{
GEORADAR DALAM PENELITIAN ARKEOLOGI DI INDONESIA
}

\section{GEORADAR IN ARCHAEOLOGICAL RESEARCHES OF INDONESIA}

\author{
M. Fadlan S. Intan \\ Pusat Penelitian Arkeologi Nasional, Jalan Raya Condet Pejaten No. 4, Jakarta selatan; \\ email:geobugis@yahoo.co.id
}

\begin{abstract}
Abstrak. Disadari bahwa kegiatan ekskavasi yang dilakukan terhadap situs arkeologi cenderung bersifat merusak, struktur lapisan tanah tidak bisa dikembalikan ke kondisi semula, ditambah dengan sifat data arkeologi yang terbatas, baik dari segi kualitas maupun kuantitas. Oleh karena itu, perlu digunakan metode yang lebih maju sehingga dengan mudah bisa menemukan data arkeologi tanpa harus membuka banyak kotak ekskavasi yang kosong. Penelitian ini bertujuan untuk memperkenalkan metode georadar yang memberikan rekomendasi terhadap lokasi anomali di bawah permukaan tanah sehingga akan mempermudah dalam proses penelitian arkeologi. Metode yang digunakan bersifat deskriptif dengan penalaran induktif. Data dikumpulkan melalui studi pustaka, baik dari sumber primer maupun sekunder. Hasil penelitian menunjukkan bahwa penggunaan metode modern sudah mulai dilakukan pada beberapa penelitian arkeologi di Indonesia, meskipun dalam jumlah yang terbatas. Oleh karena itu, diharapkan penggunaan metode georadar dapat lebih ditingkatkan bagi institusi yang berkecimpung dalam penelitian arkeologi.
\end{abstract}

Kata kunci: georadar, bawah permukaan, arkeologi

\begin{abstract}
It is well known that the excavation activities performed on archaeological sites tend to be destructive; soil layer structure can not be restored to its original condition, coupled with the limited nature of archaeological data, in terms of both quality and quantity. Therefore, it is necessary to use more advanced methods so could easily find the data without having to open many empty pits during archaeological excavation. This study aims to introduce georadar method, which provides recommendations on the location of anomalies in the subsurface that will ease the process of archaeological research. The method used is descriptive with inductive reasoning. Data were collected through literature, from both primary and secondary sources. Results of the study showed that the use of modern methods has already begun on some of the archaeological research in Indonesia, albeit in a limited number. Therefore, it is expected that the use of georadar method can be further improved for institutions which are engaged in archaeological research.
\end{abstract}

Keywords: georadar, subsurface, archaeology

\section{PENDAHULUAN}

Perkembangan penelitian arkeologi di Indonesia pada dekade terakhir ini telah memperlihatkan suatu peningkatan yang sangat pesat. Peningkatan itu perlu terus dipacu perkembangannya, agar masalah-masalah penelitian arkeologi di Indonesia dapat mengejar ketinggalannya dengan perkembangan arkeologi mutakhir di negara-negara maju lainnya (Intan 1994: 1-36). Pusat Penelitian Arkeologi Nasional (Puslit Arkenas) dan Balai Arkeologi (Balar) sebagai lembaga riset merupakan cerminan perhatian Bangsa Indonesia dalam menangani warisan budaya bangsa. Sebagai sebuah lembaga yang berwenang untuk meneliti kehidupan masa lampau, baik untuk kepentingan lokal, nasional, regional, maupun internasional, PuslitArkenas-Balar dituntut untuk selalu berperan sebagai lembaga penelitian dalam lingkup nasional yang berwawasan global. Dalam mengemban tugasnya, Puslit Arkenas dan Balar harus mampu melakukan pengembangan arkeologi Indonesia untuk kemajuan ilmu pengetahuan, menjadi agen pencerdasan bangsa dan pengembangan budaya nasional, 
serta dapat mengaktualisasikan kearifan masa lampau yang tidak lain adalah pengembangan dari jati diri bangsa (Intan 2013: 1-11).

Soejono (1982: 95-105;1990: 352-358) menyatakan bahwa prinsip arkeologi sudah tegas, yaitu mempelajari keseluruhan peristiwa di masa lampau. Prinsip inilah yang memperluas tugas kepurbakalaan, sehingga memerlukan koordinasi dalam penelitian dengan cabangcabang ilmu lainnya dan jika penelitian arkeologi ingin mencapai hasil yang lengkap dan dipercaya, maka harus memanfaatkan ilmu-ilmu eksakta atau ilmu pengetahuan alam (Soejono 1982: 95-101; 1990:352-358). Apabila kita mengikuti perkembangan arkeologi sebagai ilmu, tampak bahwa dalam setiap perkembangannya, ilmu ini tidak pernah lepas dari berbagai disiplin yang tergolong ke dalam ilmu-ilmu pengetahuan alam. Konsep, metode, teori, dan teknik yang berasal dari ilmu eksakta telah digunakan dalam arkeologi sejak awal pertumbuhannya. Bahkan dalam tahap perkembangan terakhir, teknologi modern sebagai terapan teori-teori dari ilmu tersebut, makin banyak digunakan, serta mengakibatkan perubahan-perubahan revolusioner dalam metode arkeologi. Pengamatan gejala-gejala arkeologi yang berada di dalam tanah juga dapat diamati dari permukaan dengan teknik tahanan listrik (electrical resistivity), atau geoelectric prospecting, dan teknik kelainan magnetik (magnetic anomalies), Magnetometer Proton, Magnetometer Proton Gradiometer (bleeper), Caesium Magnetometer, dan Flux-gate Magnetometer, kemagnetan (magnetics), Gravimetri Mikro (microgravimetry), dan Radar Tembus Tanah (ground penetrating radar) (Mundarjito 1983: 193-205; Sartono 1991: 1-14; Sarwono 1983: 521-532). Selain itu, masih ada pula subdisiplin ilmu yang sangat erat terkait dengan arkeologi, yaitu, pertanggalan radiokarbon, thermoluminescence, analisa neutron yang diaktifkan, metode isotop oksigen dan timbal (Sartono 1991:1-14). Metode-metode di atas akan membantu metode survei arkeologi, yang biasanya dilakukan dengan teknik dowsing, probing, augering atau besing (Mundarjito 1983: 193-205).
Salah satu permasalahan dalam penelitian arkeologi adalah dibutuhkannya kesabaran, ketelitian, dan sikap ilmiah yang tinggi, sebab data-data dari hasil penelitian arkeologi termasuk dalam data yang tidak bisa diperbaharui. Hal senada dinyatakan pula oleh Drajat (2003: 93-99) bahwa setiap kegiatan yang dilakukan terhadap benda cagar budaya dan situs pada prinsipnya adalah merusak, sehingga kegiatan total ekskavasi (excavation total) adalah kerusakan yang menyeluruh. Untuk menghindari kerusakan pada penelitian tersebut, maka salah satu cara adalah dengan merekam setiap perubahan yang terjadi pada situs tersebut (Drajat 2003: 93-99). Kondisi data dan fenomena arkeologis selalu terbatas, baik dari segi kualitas, kuantitas, maupun konteksnya. Namun demikian, ilmu arkeologi selalu diharapkan untuk mengungkap fenomena arkeologis tersebut. Oleh karena itu, ilmu arkeologi membutuhkan metodologi dan teknik dari disiplin ilmu lain untuk kepentingan penelitiannya (Said 2003: 41-58).

Kajian arkeologi pada dasarnya erat hubungannya antara kehidupan manusia di masa lalu dengan aspek ruang, baik yang berskala mikro maupun makro. Perlu diketahui bahwa studi arkeologi tidak mungkin hanya dipelajari dari tinggalan artefaktual semata, sehingga dalam memecahkan beberapa hal permasalahan arkeologi perlu pendekatan ilmu-ilmu eksakta, seperti geologi, biologi, kimia, paleontologi, dan paleoantropologi (Intan 2001: 1-11). Untuk mencapai harapan itu, maka selayaknya didukung oleh peningkatan metode-metode penelitian yang telah dikembangkan sebelumnya, baik dari dalam ilmu arkeologi itu sendiri, maupun luar ilmu arkeologi. Namun demikian, perkembangan metode itu tidak selalu dapat langsung dipinjam atau diterapkan di dalam penelitian, karena sifat data arkeologi di Indonesia memiliki karakteristik tersendiri (Sedyawati 1993: 1-15).

Permasalahan dalam kajian ini adalah bagaimana penerapan metode georadar dalam penelitian arkeologi di Indonesia? Tujuan dari penulisan ini adalah untuk memperkenalkan sebuah metode dari geofisika, yaitu georadar, yang memberikan rekomendasi lokasi anomali di bawah permukaan sehingga mempermudah 
dan membantu dalam suatu penelitian arkeologi, terutama dalam kegiatan survei sebelum dilakukan ekskavasi. Georadar (Ground Penetrating Radar) sangat tepat digunakan untuk eksplorasi dangkal (nearsurface) dengan kedalaman lebih kecil dari 25 meter, dengan ketelitian (resolusi) yang amat tinggi, serta mampu merekam data setiap $2,4 \mathrm{~cm}$, sehingga benda arkeologi bawah permukaan yang berdimensi beberapa centimeter mampu terdeteksi. Berdasarkan tujuan di atas, maka diharapkan penggunaan metode georadar dapat menjadi pertimbangan bagi institusi yang berkecimpung dalam dunia riset arkeologi, yang pada akhirnya akan membantu para peneliti dalam melaksanakan penelitian arkeologi di Indonesia.

Tulisan ini telah mengalami perubahan dan atau merupakan penyempurnaan dari tulisan yang berjudul Georadar Dalam Penelitian Arkeologi yang pernah diajukan dalam Evaluasi Hasil Penelitian Arkeologi (EHPA) di Banjarmasin pada 24 sampai dengan 28 Oktober 2011.

\section{METODE}

Penelitian ini merupakan penelitian studi kasus, yaitu sebuah bentuk penelitian kualitatif yang difokuskan pada tersedianya sebuah perhitungan detail dari satu kasus atau lebih (Kuntjojo 2009: 1-57). Oleh karena itu, tulisan ini bersifat deskriptif dengan penalaran induktif. Data dikumpulkan melalui kajian pustaka, baik dari sumber primer maupun sekunder. Selanjutnya, data dianalisis untuk menjawab permasalahan.

\section{HASIL DAN PEMBAHASAN}

\section{Konsep Dasar Pengukuran Georadar}

Di negara-negara maju, penelitian arkeologi yang menerapkan ilmu geofisika disebut arkeofisika. Metode ini tidak merusak (non destructive) artefak arkeologis yang berada di dalam tanah (Sarwono 1983: 521-532; Intan 1994: 1-36;Sartono 1991: 1-14). Dalam geofisika ada beberapa metode yang digunakan yaitu, 1) Geomagnet (geomagnetic), mempelajari bawah permukaan berdasarkan sifat kemagnetan batuan.
Sifat kemagnetan batuan sangat bergantung pada sifat suseptibilitas dan remanen magnet. Alat yang digunakan dalam metode ini adalah magnetometer; 2) Geolistrik (geoelectric), terkait dengan sifat kelistrikan yang bisa diamati, yaitu resistivitas, konduktivitas, chargeability, dan potensial yang di bumi itu sendiri. Alat yang digunakan dalam metode ini adalah geolistrik; 3) Seismik, mengukur kecepatan penjalaran gelombang getar/gempa. Kecepatan gelombang ini sangat berhubungan dengan densitas dan modulus of elasticity batuan bawah permukaan. Alat yang digunakan dalam metode ini adalah seismometer; 4) Gravimetri-mikro (microgravimetry), mengukur nilai gaya berat suatu kawasan berdasarkan perbedaan densitas/ massa jenis batuan bawah permukaan bumi. Alat yang digunakan dalam metode ini adalah gravimeter; 5) Elektromagnetik, mengukur gelombang elektromagnetik yang berasal dari lapisan ionosfer lalu merambat ke bawah permukaan bumi dan menginduksi material konduktif sehingga menghasilkan gelombang elektromagnetik sekunder. Alat yang digunakan dalam metode ini adalah TURAM EM - Scintrex, VLF-T-IRIS; dan 6) Georadar, mengukur waktu perambatan gelombang radio yang dipancarkan dan diterima kembali oleh alat. Alat yang digunakan dalam metode ini adalah GPR (ground penetrating radar) (Sarwono 1983: 521-532; Intan 1994: 1-36; Sartono 1991: 1-14).

Metoda Ground Penetrating Radar (GPR) atau georadar, menggunakan prinsip perambatan pulsa elektromagnetik dipancarkan ke dalam bumi dan direkam oleh antena di permukaan. Pulsa radar diteruskan, dipantulkan, dan dihamburkan oleh struktur permukaan dan anomali di bawah permukaan (lihat gambar 1).

Georadar merupakan salah satu metode geofisika yang menggunakan sumber gelombang elektromagnetik (EM) yang menggunakan gelombang radio dengan frekuensi antara 1-1000 $\mathrm{MHz}$. Georadar menggunakan gelombang elektromagnet dan memanfaatkan sifat radiasinya yang memperlihatkan refleksi seperti pada metode seismik refleksi. Kelebihan lain georadar adalah biaya operasionalnya yang rendah, 


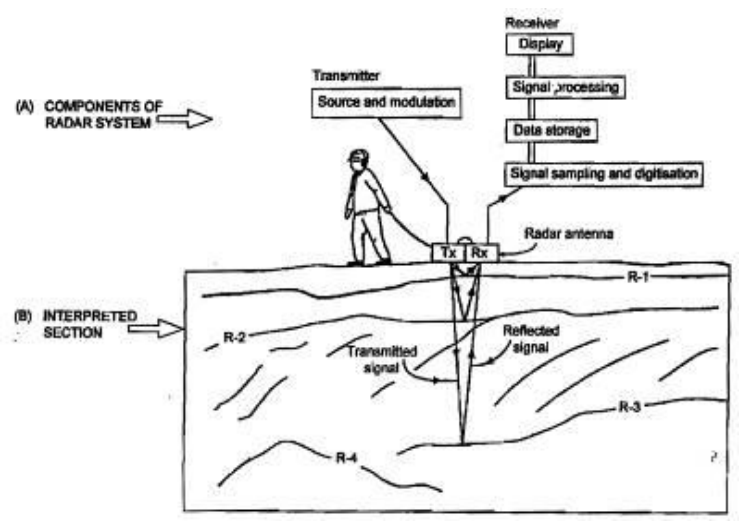

sumber: Arisona 2009

Gambar 1. Diagram skema komponen-komponen yang dimiliki oleh georadar

prosedur pengerjaan mudah, dan ketelitian sangat tinggi (resolusi tinggi). Kelemahannya, penetrasinya tidak terlalu dalam atau daya tembus metode ini hanya sampai puluhan meter $( \pm 100$ meter). GPR telah populer di dunia sejak pertengahan 1980-an, khususnya di bidang geologi teknik dan arkeologi (Arisona 2012: 610; Khumaidi dan Ismail 2013: 28-33; Zulaikah dkk. 2015: 52-54). Keunggulan yang dimiliki metode ini antara lain keakuratan dalam mendeteksi struktur bawah permukaan seperti air tanah, fosil, data arkeologi, geoteknik, eksplorasi bahanbahan mineral, pendeteksian pencemaran lingkungan, dan pemetaan ketebalan lapisan es kutub (Arisona 2009: 46-53). Hal itu disebabkan panjang gelombang mencerminkan ukuran minimum benda yang dapat terdeteksi. Makin tinggi frekuensi makin kecil panjang gelombang, sehingga makin kecil ukuran benda yang dapat terdeteksi (makin tinggi pula ketelitiannya). Hasil pencitraan georadar bisa memunculkan informasi semacam ketebalan permukaan aspal jalan, jalur pipa bawah tanah untuk mencari bedrock yang pas guna fondasi bangunan hingga mencari lokasi-lokasi situs arkeologi (Arisona 2009: 4653).

Pengukuran dengan menggunakan georadar ini merupakan metode yang tepat untuk mendeteksi benda-benda kecil yang berada di dekat permukaan bumi (0,1-3 meter) dengan resolusi yang tinggi yang artinya konstanta dielektriknya menjadi rendah. Ada tiga jenis pengukuran, yaitu refleksi, velocity sounding, dan transillumination. Pengukuran refleksi biasa disebut Continuous Reflection Profiling (CRP). Pengukuran velocity sounding disebut Common Mid Point (CMP) untuk menentukan kecepatan versus kedalaman, dan transillumination disebut juga GPR Tomografi.

Secara keseluruhan, alat georadar berbobot tidak lebih dari lima kilogram, sehingga sangat leluasa bergerak. Alat ini bekerja dengan dua antena. Satu berfungsi sebagai pemancar (transmiter), yaitu bertugas memancarkan gelombang radar. Lainnya sebagai penerima (receiver), bertugas menerima gelombang radar yang dipantulkan bahan di sekelilingnya kemudian diolah grafiknya ke dalam komputer

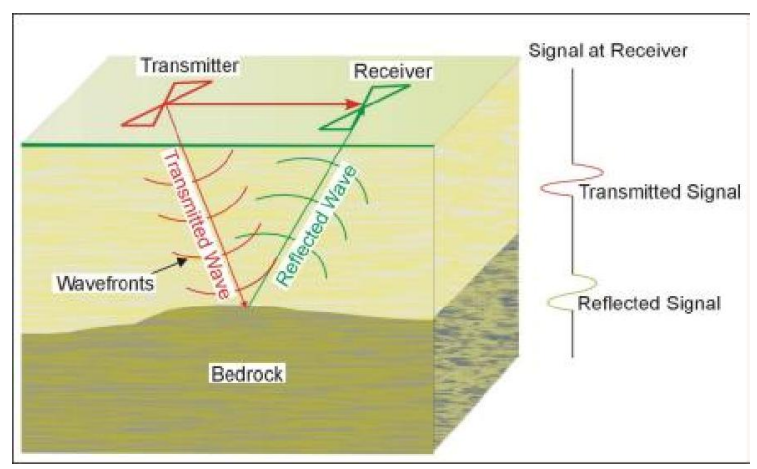

sumber: Syaeful dkk. 2009

Gambar 2. Konsep akuisisi data

(lihat gambar 2). Pada prinsipnya, metode georadar dengan metode seismik sama, yaitu membangkitkan gelombang buatan ke dalam bumi. Perbedaannya hanya pada jenis gelombang yang digunakan (Budiono dkk. 2010: 18-195).

Prinsip kerja alat georadar adalah dengan mentransmisikan gelombang radar (Radio Detection and Ranging) ke dalam medium target, dan selanjutnya gelombang tersebut dipantulkan kembali ke permukaan dan diterima oleh alat penerima radar (receiver), dari hasil refleksi itulah berbagai macam objek dapat terdeteksi dan terekam dalam radargram. Mekanisme kerja georadar dan contoh rekaman radargram ditunjukkan oleh gambar 3 .

Georadar terdiri dari sebuah pembangkit sinyal, antena transmitter, dan receiver sebagai pendeteksi gelombang EM yang dipantulkan. Sinyal radar ditransmisikan sebagai pulsa-pulsa yang tidak terabsorbsi oleh bumi tetapi dipantulkan dalam domain waktu tertentu. Mode 


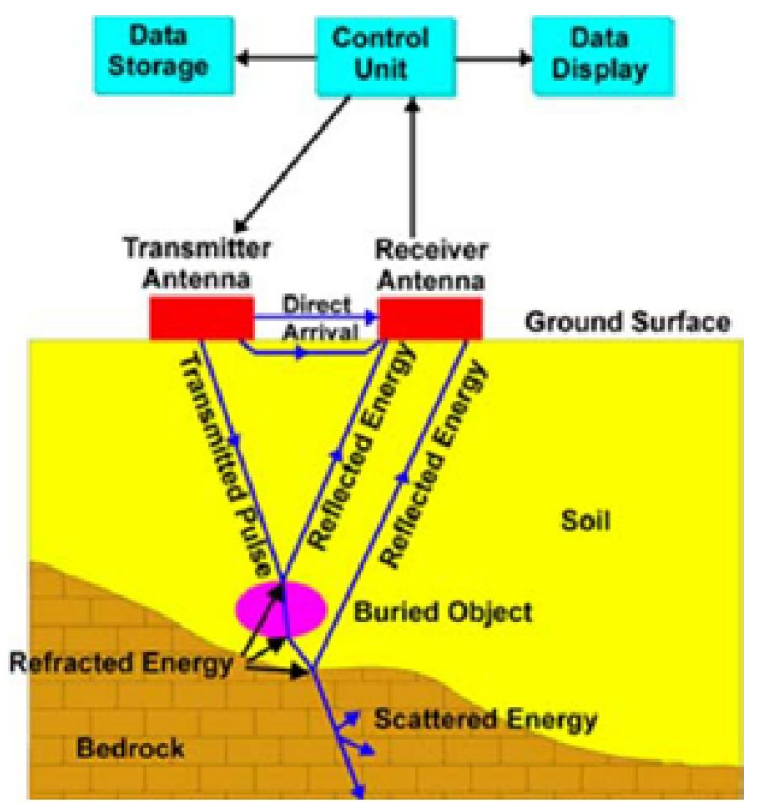

sumber: Syaeful dkk. 2009

Gambar 3. Akuisisi data GPR

konfigurasi antena transmitter dan receiver pada georadar terdiri dari mode monostatik dan bistatik. Mode monostatik bila transmitter dan receiver digabung dalam satu antena, sedangkan mode bistatik bila kedua antena memiliki jarak pemisah.

Untuk mendeteksi suatu objek diperlukan perbedaan parameter kelistrikan dari medium yang dilewati gelombang radar. Perbedaan parameter kelistrikan antara lain adalah permitivitas listrik, konduktivitas, dan permeabilitas magnetik.

Sifat elektromagnetik suatu material bergantung pada komposisi dan kandungan air di dalamnya, di mana keduanya merupakan pengaruh utama pada perambatan kecepatan gelombang radar dan atenuasi gelombang elektromagnetik dalam material. Reynold (2011:1710) dalam bukunya An Introduction to Applied and Evironmental Geophysics, menyatakan bahwa kecepatan gelombang radar dalam suatu medium tergantung pada kecepatan cahaya dalam ruang hampa ( $c=0.3 \mathrm{~m} / \mathrm{ns}$ ), konstanta dielektrik relatif medium (år) dan permeabilitas magnetik relatif (ir).

Transmitter membangkitkan pulsa gelombang EM pada frekuensi tertentu sesuai dengan karaketristik antena tersebut $(10 \mathrm{MHz}-4$ $\mathrm{GHz}$ ). Receiver diset untuk melakukan pemindaian yang secara normal mencapai 32512 scan per detik. Setiap hasil scan ditampilkan pada layar monitor (real-time) sebagai fungsi waktu two-way traveltime, yaitu waktu yang dibutuhkan gelombang EM menjalar dari transmitter, target, dan receiver. Tampilan ini disebut radargram.

Metode georadar didasarkan atas persamaan Maxwell yang merupakan perumusan matematis untuk hukum-hukum fisika yang mendasari semua fenomena elektromagnetik. Persamaan Maxwell terdiri dari empat persamaan medan, masingmasing dapat dipandang sebagai hubungan antara medan distribusi sumber (muatan atau arus) yang bersangkutan (Deniyatno 2011: 69-76). Persamaan Maxwel ini adalah landasan berpikir dari perambatan gelombang elektromagnet. Pada material dielektrik murni, suseptibilitas magnetik (i) dan permitivitas listrik $\left(^{\circ}\right)$ adalah konstan dan tidak terdapat atenuasi dalam perambatan gelombang. Tidak sama halnya jika berhadapan dengan material dielektrik yang ada. Sifat-sifat dari material bumi bergantung dari komposisi dan kandungan air material tersebut. Keduanya ini mempengaruhi cepat rambat gelombang dan atenuasi gelombang elektromagnet.

Keberhasilan dari metode georadar bergantung pada variasi bawah permukaan yang dapat menyebabkan gelombang tertransmisikan. Perbandingan energi yang direfleksikan disebut koefisien refleksi $(R)$ yang ditentukan oleh perbedaan cepat rambat gelombang elektromagnet dan lebih mendasar lagi adalah perbedaan dari konstanta dielektrik relatif dari media yang berdekatan. Dalam semua kasus, besarnya $\mathrm{R}$ terletak antara -1 dan 1 , bagian dari energi yang ditransmisikan sama dengan 1-R. Persamaan tersebut diaplikasikan untuk keadaan normal pada permukaan bidang datar. Dengan asumsi tidak ada sinyal yang hilang sehubungan dengan amplitudo sinyal.

Besar amplitudo rekaman georadar $r(t)$ akan tampak pada penampang rekaman georadar berupa variasi warna. Refleksi atau transmisi di sekitar batas lapisan menyebabkan energi hilang. Jika kemudian ditemukan benda yang memiliki dimensi yang sama dengan panjang gelombang dari sinyal gelombang elektromagnet maka benda ini menyebabkan penyebaran energi secara acak. Absorbsi (mengubah energi elektromagnet menjadi energi panas) dapat 
menyebabkan energi hilang. Penyebab yang paling utama hilangnya energi karena atenuasi fungsi kompleks dari sifat listrik dan dielektrika media yang dilalui sinyal radar. Atenuasi (á) tergantung dari konduktifitas (ó), permeabilitas magnetik (i), dan permivitas $\left(^{\circ}\right)$ dari media yang dilalui oleh sinyal dan frekuensi dari sinyal itu sendiri (2ðf). Sifat dielektrik dari material ditentukan oleh sifat fisik dari unsur pokok yang ada dan komposisinya. Dalam perambatannya, amplitudo sinyal akan mengalami pelemahan karena adanya energi yang hilang, sebagai akibat terjadinya refleksi/transmisi di tiap batas medium dan terjadi setiap kali gelombang radar melewati batas antarmedium. Faktor kehilangan energi disebabkan oleh perubahan energi elektromagnetik menjadi panas. Penyebab dasar terjadinya atenuasi merupakan fungsi kompleks dari sifat dielektrik dan sifat listrik medium yang dilewati oleh sinyal radar. Faktor atenuasi tergantung pada konduktivitas, permitivitas, dan permeabilitas medium magnetik, di mana sinyal tersebut menjalar, serta frekuensi sinyal itu sendiri. Skin depth adalah kedalaman di mana sinyal telah berkurang menjadi $1 / e$, sedangkan untuk material geologi, berada pada range 1-30, sehingga range jarak cepat rambat gelombang menjadi besar yaitu sekitar 0.03 sampai $0.175 \mathrm{~m} / \mathrm{ns}$.

\section{Perolehan Data Georadar}

Ada beberapa metode berbeda untuk memperoleh data georadar, salah satunya yang paling umum digunakan adalah mendorong suatu unit georadar sepanjang lintasan (lihat gambar 4A, $B$, dan $C$ ). Ketika unit georadar bergerak di sepanjang garis survei, pulsa energi dipancarkan dari antena pemancar dan pantulannya diterima oleh antena penerima. Antena penerima mengirimkan sinyal ke recorder. Komponen utama untuk dipertimbangkan dalam memperoleh data georadar adalah jenis transmisi dan antena penerima yang menggunakan cakupan frekuensi yang tersedia untuk pulsa elektromagnetik. Kecepatan sinyal elektromagnetik dan panjang gelombang sinyal dapat ditentukan dari pengukuran tersebut (Yulius dkk. 2008: 1-6;
Hakim dkk. 2011: 1-100; Jufri dkk. tanpa tahun:19).

\section{Pengolahan Data Georadar}

Setelah memperoleh data georadar, maka data ini harus diproses. Pengolahan data georadar melibatkan modifikasi sehingga dapat lebih mudah divisualisasikan dan diinterpretasi.

Pada banyak kasus, survei georadar dengan pengolahan data yang sangat minim mungkin saja dapat dipakai hasilnya. Dalam kasus ini, satusatunya penyesuaian yang perlu untuk dibuat adalah konversi data ke suatu penggunaan format digital, melakukan penyesuaian penguatan data, dan menentukan kedalaman setiap reflektor di bawah permukaan. Berikut adalah langkahlangkah yang diperlukan untuk memproses data survei georadar (Yulius dkk. 2008:1-6; Hakim dkk. 2011: 1-100; Jufri dkk. tanpa tahun:1-9):

1. Konversi data ke penggunaan format digital. Pada kebanyakan unit georadar, data secara otomatis direkam dalam format digital atau data unit georadar yang diperoleh dimasukkan ke komputer dan diproses dengan perangkat lunak.

2. Penghilangan atau minimalisasi gelombang direct dan gelombang udara dari data. Seringkali ada amplitudo refleksi yang besar pada batas antara permukaan udara dan tanah seketika di bawah antena georadar. Kontras yang tinggi antara daya konduktivitas udara dan tanah dapat menciptakan gelombang direct dan gelombang udara yang dapat mengaburkan refleksi dari objek penting di bawah permukaan. Gelombang direct dan gelombang udara ini dapat dihilangkan dengan komputasi waktu tempuh dan panjang gelombang, kemudian dengan mengurangkan gelombang teoritis sepanjang lebar panjang gelombang dari gelombang aslinya pada setiap trace georadar.

3. Penyesuaian amplitudo pada data. Dalam banyak kasus, baterai unit georadar dapat melemah saat survei masih berlangsung. Ini menghasilkan 


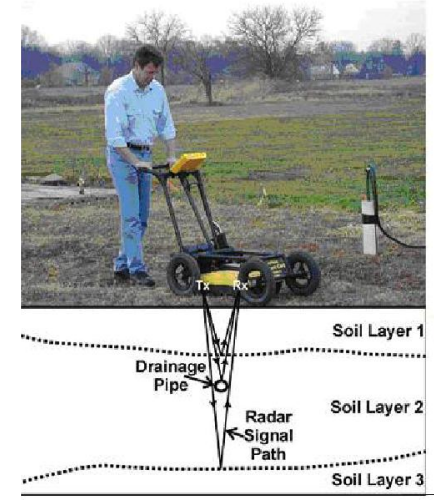

$4 \mathrm{~A}$

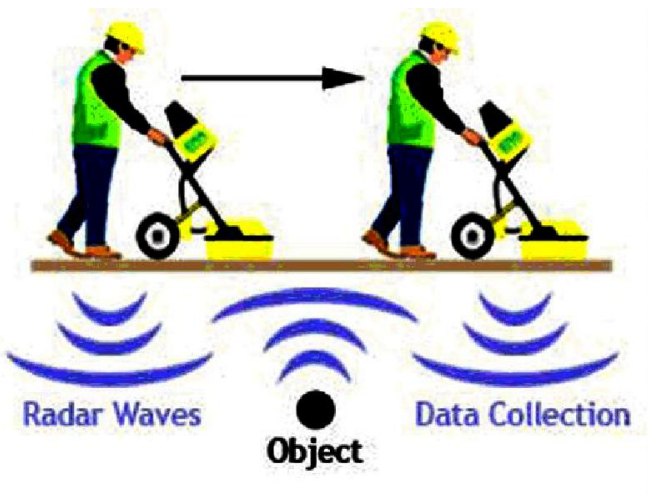

4B

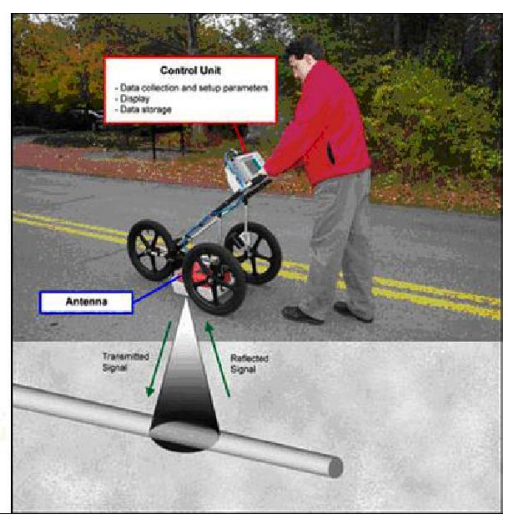

4C

sumber: Gambar 4A Yulius dkk. 2008:6; Gambar 4B Payne 2013:1-4; Gambar 4C Hakim dkk. 2011:1-100

Gambar 4. Sistem kerja georadar yang didorong

trace georadar dengan amplitudo refleksi yang semakin lemah. Menentukan waktu habisnya baterai dari waktu ke waktu, kemudian mengalikan masing-masing trace dengan suatu konstanta untuk memperbaiki pengurangan tadi dapat mengoreksi masalah ini.

4. Penyesuaian penguatan pada data. Selama sinyal transmisi dari unit georadar menembus tanah, terjadi atenuasi terhadap trace georadar. Atenuasi itu dapat dikoreksi dengan melakukan penyesuaian penguatan pada setiap trace. Ada beberapa persamaan untuk komputasi penyesuaian penguatan. Dalam satu model, masing-masing nilai data pada keseluruhan jejak dikalikan dengan suatu faktor yang berhubungan dengan kedalaman sinyal.

5. Penyesuaian status. Penyesuaian ini untuk menghilangkan efek yang disebabkan oleh perubahan elevasi dan peningkatan antena georadar.

6. Filtering data. Tujuan dari filtering adalah untuk menghilangkan noise background yang tidak diinginkan. Untuk menghilangkan noise yang tidak diinginkan ini, data trace time-domain dikonversi dalam bentuk domain frekuensi dengan menggunakan transformasi Fourier. Frekuensi yang

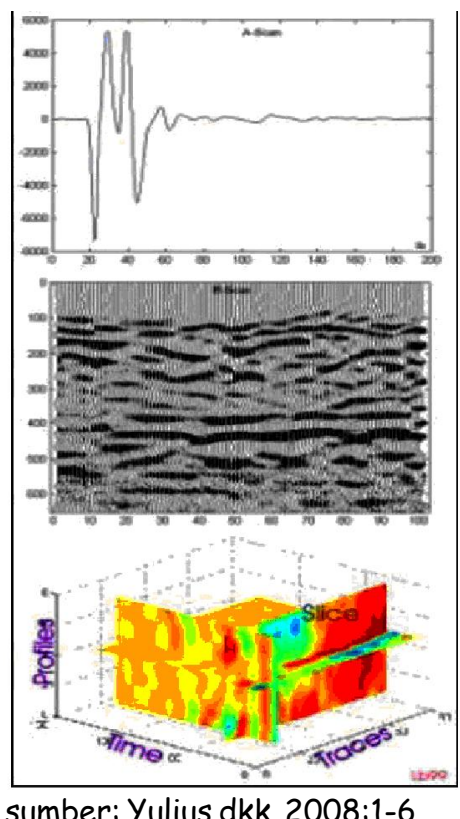

Gambar 5. Gambar data GPR A-scan (1D), B-scan (2D), dan C-scan (3D)

diinginkan disaring, dan trace dikonversi kembali menjadi domain time dengan menggunakan invers transformasi Fourier.

7. Velocity analysis, melibatkan penentuan kecepatan gelombang pada material bawah permukaan, kemudian mengubah travel time ke kedalaman dengan pengujian konstanta dielektrik relatif.

8. Migrasi, yaitu suatu prosedur untuk mengubah permukaan yang telah terekam dalam data georadar ke data dengan lokasi heterogenetis bawah permukaan pada posisi yang benar. 
Visualisasi Data GPR

Ada tiga metode dalam memvisualisasi data GPR, antara lain A-scan adalah penyajian 1D single profil GPR (trace), B-scan adalah penyajian 2D rangkaian trace GPR, dan $\mathrm{C}$-scan adalah penyajian 3D rangkaian trace $2 \mathrm{D}$ (lihat gambar 5 ).

\section{Kedalaman Penetrasi Georadar}

Bagaimanapun data diproses dan divisualisasi, sebuah unit georadar memiliki batas penetrasi kedalaman. Ketika pulsa elektromagnetik dipancarkan seiring kedalaman tertentu, secara cepat memudar dan menghilang. Kedalaman penetrasi sinyal georadar bergantung pada: a) frekuensi sumber sinyal georadar; b) efisiensi radiasi antena georadar; dan c) sifat elektrik material bawah permukaan.

\section{Interpretasi Data Georadar}

Prosedur interpretasi data georadar untuk penentuan geologi bawah permukaan dangkal dan untuk menentukan kondisi hidrogeologi. Interpretasi ini kemudian biasa dikombinasikan dengan interpretasi dari log borehole dan metode geofisika lainnya untuk pencirian bawah permukaan yang lebih akurat.

\section{Prosedur Penentuan Geologi Bawah Permukaan Dangkal}

Penentuan geologi bawah permukaan lebih mengarah pada seni daripada sains. Prosedur untuk menentukan geologi bawah permukaan dangkal dari data georadar dengan menggunakan parameter yang tergambar dalam gambar 6 (Yulius dkk. 2008:1-6). Setelah menginterpretasikan survei, mereka menggunakan data borehole dan data geofisika untuk memverifikasi dan mengkalibrasi hasil interpretasi bawah permukaan (lihat gambar 7). Dalam semua kasus interpretasi data, interpretasi dikalibrasikan dengan data bawah permukaan yang telah diketahui, atau dibandingkan dengan data yang diperoleh dari metode geofisika lainnya (lihat gambar 8). Untuk menentukan geologi bawah permukaan dangkal dari data georadar dilakukan pendekatan sebagai berikut: a) melakukan survei georadar; b) memproses data dari survei georadar; c) menggunakan tipe
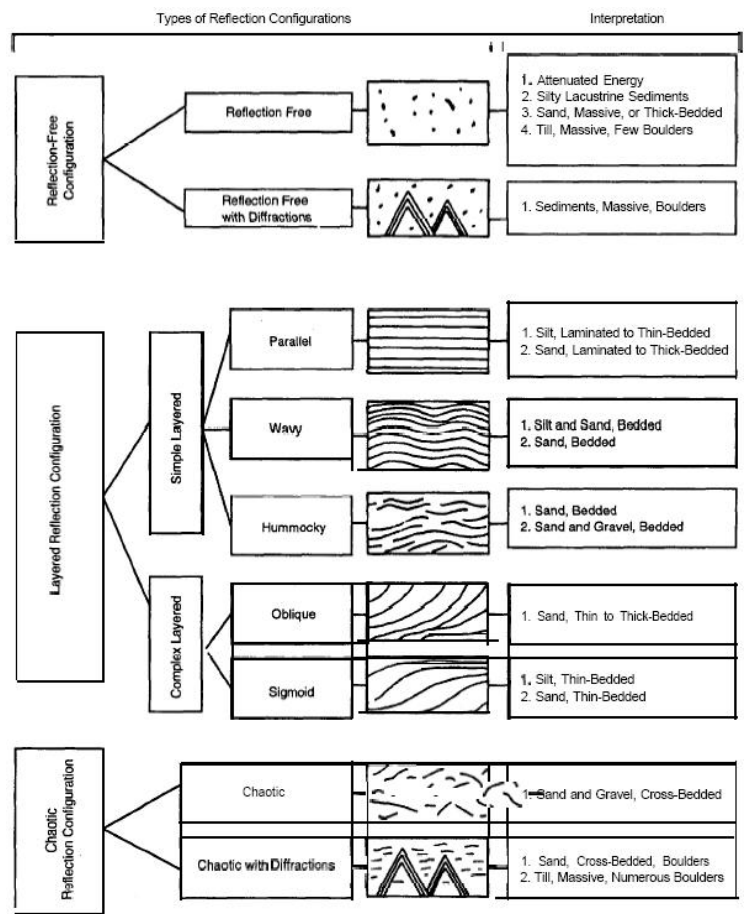

sumber: Beres and Haeni 1991, dalam Yulius dkk. 2008: $1-6$

Gambar 6. Penentuan tipe sedimen bawah permukaan

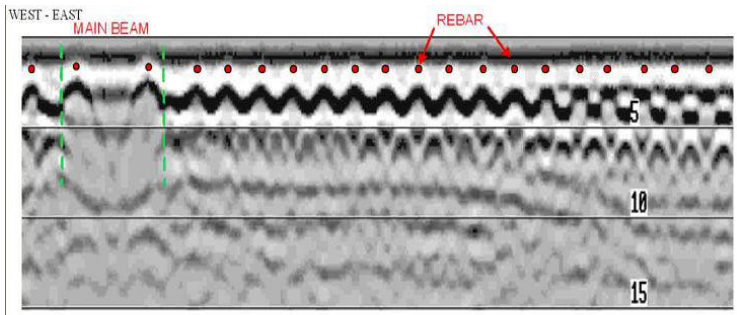

sumber:Takahashi dkk. 2012:155-180

Gambar 7. Hasil verifikasi dan kalibrasi dari data geofisika

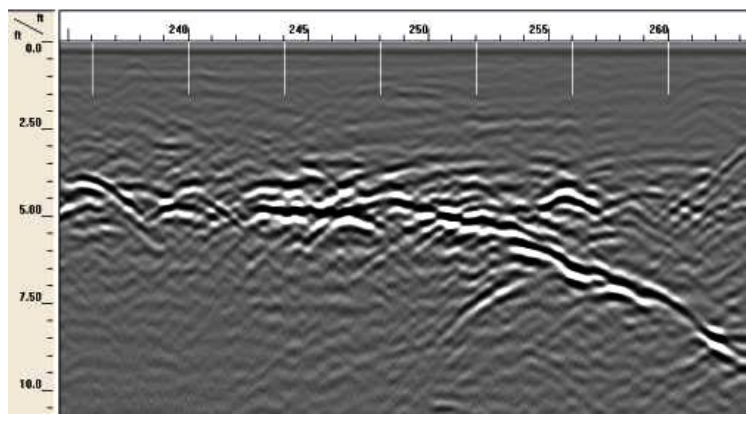

sumber:Takahashi dkk. 2012:155-180

Gambar 8. Hasil kalibrasi yang disebandingkan dengan metoda geofisika lainnya 
sedimen bawah permukaan untuk menentukan geologi bawah permukaan dan; d) kalibrasi geologi bawah permukaan yang diperoleh dari data georadar dengan data borehole, rekaman geologi bawah permukaan yang telah diketahui, dan metode geofisika lainnya.

\section{Georadar dan Arkeologi}

Metode Ground Penetrating Radar(GPR) atau georadar telah banyak digunakan di berbagai bidang seperti geologi, arkeologi, geoteknik, lingkungan, geohidrologi, dan beberapa kasus lainnya. Metode ini berhasil pula diterapkan pada penentuan lokasi dan cadangan sumber mineral, pendeteksian pencemaran lingkungan, pemetaan ketebalan lapisan es kutub, pendeteksian benda arkeologi yang terkubur, dan lain sebagainya.

Selanjutnya, akan diberikan beberapa contoh model kasus hasil pengukuran georadar, yang telah dilakukan oleh Untoro (1999: 78-89) untuk memperlihatkan kemampuan metode ini mendapatkan citra geometri yang berongga yang terletak di bawah permukaan, mendapatkan citra dari benda yang relatif kecil (pipa besi), dan benda keramik (tanah liat) (Untoro 1999: 78-89).

Pemilihan antena georadar merupakan hal yang penting berkaitan dengan ukuran dan kedalaman target yang diinginkan. Pada eksperimen ini digunakan 3 (tiga) jenis frekuensi antena, masing-masing $900 \mathrm{MHz}, 500 \mathrm{MHs}$, dan $100 \mathrm{MHz}$. Kedalaman target yang diharapkan dengan frekuensi $900 \mathrm{MHz}$ bervariasi antara 0,51,0 meter dengan asumsi nilai konstanta dielektrik $=5,0$. Untuk frekuensi $500 \mathrm{MHz}$, kedalaman target bervariasi antara 3,0-5,0 meter dengan asumsi nilai konstanta dielektrik $=9,0$. Untuk frekuensi $100 \mathrm{MHz}$, kedalaman target bervariasi antara 12,025,0 meter dengan asumsi konstanta dielektrik = 9.0 (Untoro 1999: 78-89).

\section{Model Geometri Berongga}

Model dengan dimensi berongga, di sekitarnya berupa tanah urugan dan bagian atasnya tertutup jalan aspal. Model bentuk rongga seperti ini sangat sulit dicitrakan dengan metodemetode geofisika lainnya. Dengan menggunakan

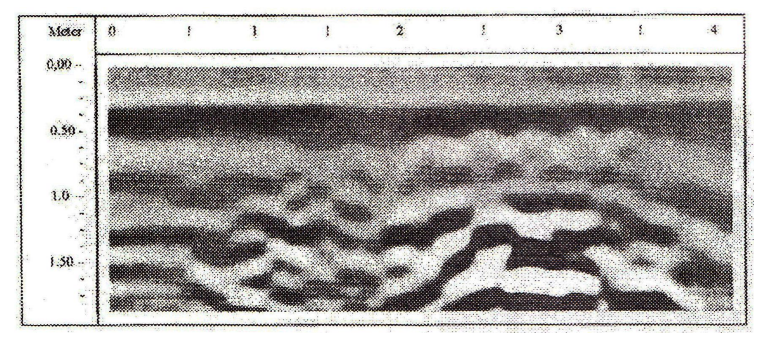

sumber: Untoro 1999:78-89

Gambar 8. Citra georadar dengan obyek saluran bawah permukaan (data lapangan dengan frekuensi lolos rendah $1000 \mathrm{MHz}$, lolos tinggi $125 \mathrm{MHz}$ )

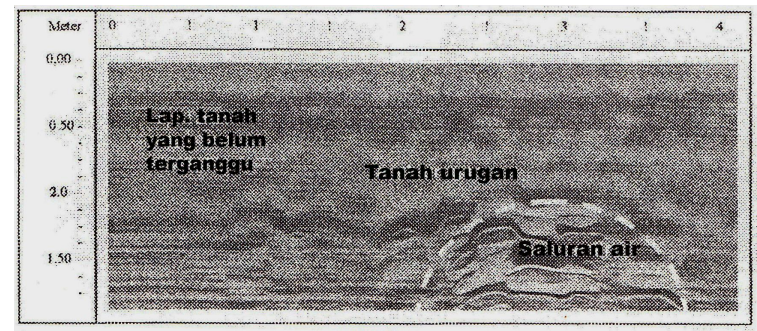

sumber: Untoro 1999:78-89

Gambar 9. Citra georadar setelah dilakukan proses dekonvolusi (dengan parameter operator length 31, prediction lag 6 dan prewhitening 0,1\%)

antena georadar $500 \mathrm{MHz}$ diperoleh citra seperti diperlihatkan gambar 9 dan gambar 10. Geometri rongga tersebut dapat dicitrakan dengan baik. Penguatan amplitude pada bagian ini akibat pengaruh kontras impedansi yang kuat dari beton batas rongga dengan udara. Di sekitar goronggorong berupa lapisan tanah urugan yang belum begitu kompak, yang digambarkan sebagai pola refleksi yang tidak kontinyu, sedangkan refleksi yang menerus pada bagian atas adalah refleksi dari jalan aspal. Dari kenyataan di atas, maka metoda georadar dapat mencitrakan terowongan, jembatan dan target-target berongga lainnya di bawah permukaan, seperti rongga-rongga dalam daerah karst sehubungan dengan eksplorasi air tanah. Untuk target yang lebih dalam dapat dilakukan dengan menggunakan antena georadar dengan frekuensi gelombang yang lebih rendah (Untoro 1999: 78-89).

Pada tahap berikutnya, dilakukan migrasi terhadap bentuk geometri yang lebih kompleks, yang terdiri dari tiga buah lingkaran yang menggambarkan seolah-olah lempeng logam dan pipa. Hasil dari model yang belum dimigrasi ditunjukkan oleh gambar 11. Pada gambar 11a 

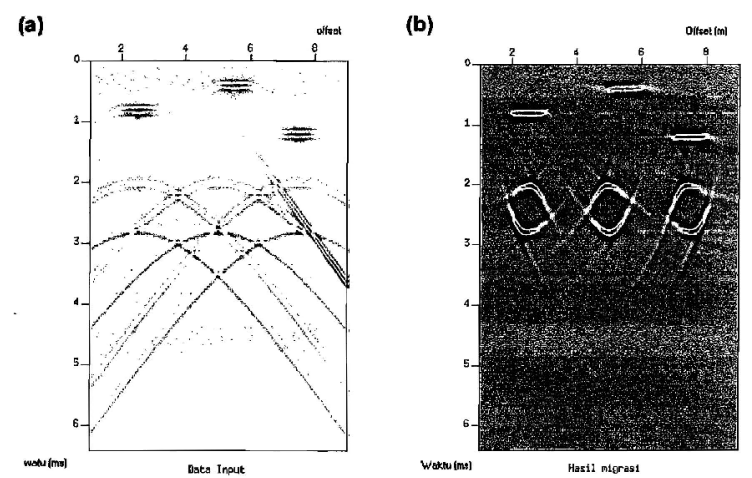

sumber: Arisona 2009:46-53

Gambar 11. (a) Data sintetik garis dan lingkaran; (b) Hasil migrasinya

tampak pola-pola difraksi yang muncul pada ujung-ujung garis dan juga pada lingkaran bagian atas dan bawah. Pola-pola difraksi ini hilang setelah dilakukan migrasi seperti yang digambarkan oleh gambar 11b (Arisona 2009: 4653)

\section{Model Pipa Besi}

Model pasangan pipa besi berukuran sama dengan diameter $3,5 \mathrm{~cm}$ dan pasangan pipa besi dengan ukuran berbeda. Masing-masing berdiameter $3,5 \mathrm{~cm}$ dan $9,0 \mathrm{~cm}$ dipendam pada batuan lempung pasiran dengan kedalaman 30 $50 \mathrm{~cm}$ (lihat gambar 12a). Pengukuran georadar menggunakan antena $900 \mathrm{MHz}$. Maksud dari pengukuran ini adalah untuk melihat kemampuan mendeteksi benda-benda kecil yang terletak di bawah permukaan. Hasil citra georadar diperlihatkan pada gambar 12b. Dari citra tersebut terlihat bahwa keberadaan benda anomali berupa pipa besi dapat dikenali dari pola difraksinya. Keberadaan masing-masing pipa sulit dipisahkan, terutama pasangan pipa ukuran $3,5 \mathrm{~cm}$. Untuk model pasangan pipa besi dengan ukuran berbeda nampak masih dapat menunjukkan adanya dua puncak difraksi pada posisi yang berbeda. Untuk mencari posisi benda secara tepat dilakukan proses migrasi yang bermaksud untuk memfokuskan sinyal pada posisi benda. Hasil migrasi diperlihatkan pada gambar 12c. Dari gambar tersebut terlihat bahwa posisi benda lebih terfokuskan pada pola-pola difraksi sudah tereduksi. Gambar 12d adalah citra yang dilakukan proses dekonvolusi. Dari gambar
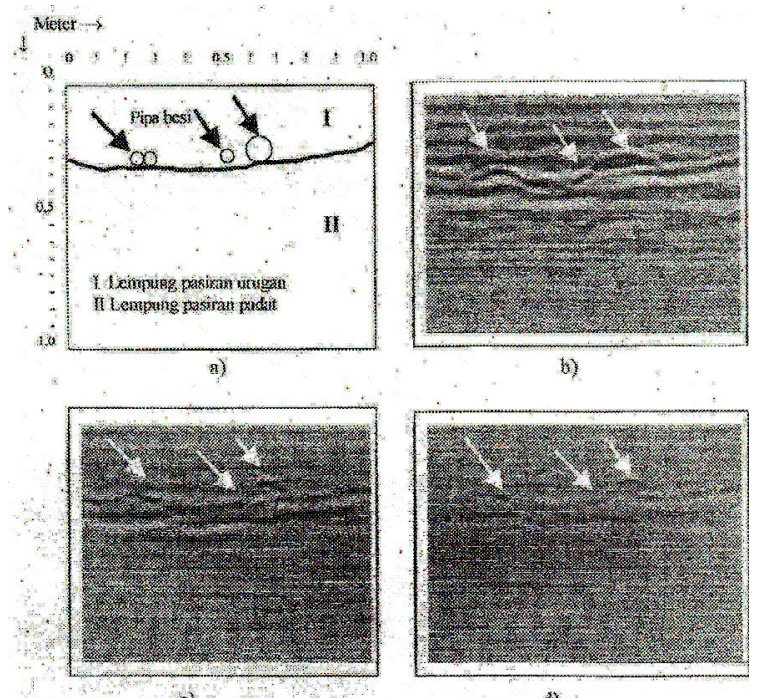

sumber: Untoro 1999:78-89

Gambar 12. Pemodelan obyek dengan dimensi kecil terbuat dari pipa besi (a) Skema bentuk dan lokasi obyek; (b) Citra georadar data lapangan; (c) Citra georadar setelah dimigrasi; (d) Citra georadar setelah didekonvolusi dan migrasi

Keterangan: Data lapangan diambil dengan filter frekuensi lolos rendah $1800 \mathrm{MHz}$ dan lolos tinggi $225 \mathrm{MHz}$. Proses migrasi menggunakan metode Kirchhoff dengan kecepatan relative 0,28 dan lebar hiperbola $63 \mathrm{scan}$. Proses dekonvolusi menggunakan parameter operator length 3,5 prediction lag 6 dan prewhitening $0,2 \%$.

tersebut pola ringing sudah tereduksi dan target benda anomali lebih menonjol. Pemilihan parameter yang tepat pada proses dekonvolusi dan migrasi merupakan hal yang sangat penting untuk dapat menentukan keberadaan dan posisi dari benda objek. Dari hasil pencitraan ini memperlihatkan bahwa metode georadar mampu mendeteksi benda-benda dengan ukuran relatif kecil. Benda dengan ukuran tersebut sangat sulit dideteksi dengan metoda geofisika lainnya (Untoro 1999: 78-89).

Arisona (2009: 46-53) mengajukan hasil pengukuran georadar yang ditunjukkan pada gambar 13a. Dari tampilan citra data georadar tampak pola difraksi yang diakibatkan oleh pipa PVC, pipa besi, dan galon air pada kedalaman 1 meter dari atas. Bagian bawah pada kedalaman 1,5 meter juga ada pola-pola difraksi yang menyerupai pola difraksi yang diakibatkan oleh pipa, yang kemungkinan merupakan perulangan pola difraksi di bagian atas. Pola-pola difraksi ini hilang setelah dilakukan migrasi dan hiperbola difraksi mengumpul pada puncak hiperbola pada 


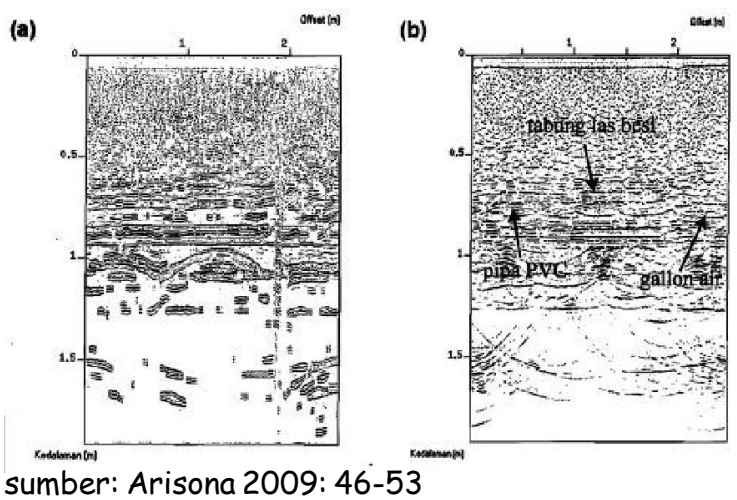

Gambar 13. (a) Raw data setelah difilter $A G C$; (b) Hasil migrasi

kedalaman 1 meter sehingga citra pipa PVC, pipa besi, dan galon air menjadi jelas seperti yang ditunjukkan oleh gambar $13 \mathrm{~b}$ (Arisona 2009: 46-53).

Model Benda Keramik dan Pipa Tanah Liat

Model benda keramik dengan ukuran kurang lebih 9,0 cm dan pipa tanah liat dengan diameter $17,0 \mathrm{~cm}$ dipendam dalam tanah lempung pasiran pada kedalaman kurang lebih 1,0 meter, seperti yang diperlihatkan pada gambar $14 a$. Pengukuran georadar menggunakan antena $900 \mathrm{MHz}$. Tujuan pengukuran ini adalah untuk pemodelan objek arkeologi dari bahan tanah liat dan keramik. Gambar 14b memperlihatkan citra georadar dari hasil pengukuran langsung di lapangan. Adanya indikasi kedua anomali tersebut di atas dapat dilihat dari respon refleksi georadar berupa gundukan yang menggambarkan respon refleksi benda anomali dan pola difraksi yang dibangkitkan. Respon amplitudo yang dibangkitkan dari bahan keramik dan tanah liat relatif lebih lemah dibandingkan dengan pipa besi seperti yang diperlihatkan pada gambar 14b. Untuk menghilangkan efek difraksi dilakukan proses migrasi, hasilnya diperlihatkan pada gambar 14c. Untuk menghilangkan efek multiple dilakukan proses dekonvolusi, hasilnya diperlihatkan pada gambar 14d. Metode georadar juga mampu untuk mencitrakan benda-benda dengan geometri yang tidak beraturan, maka metode georadar sangat berperan dalam bidang geoarkeologi (Untoro 1999: 78-89).
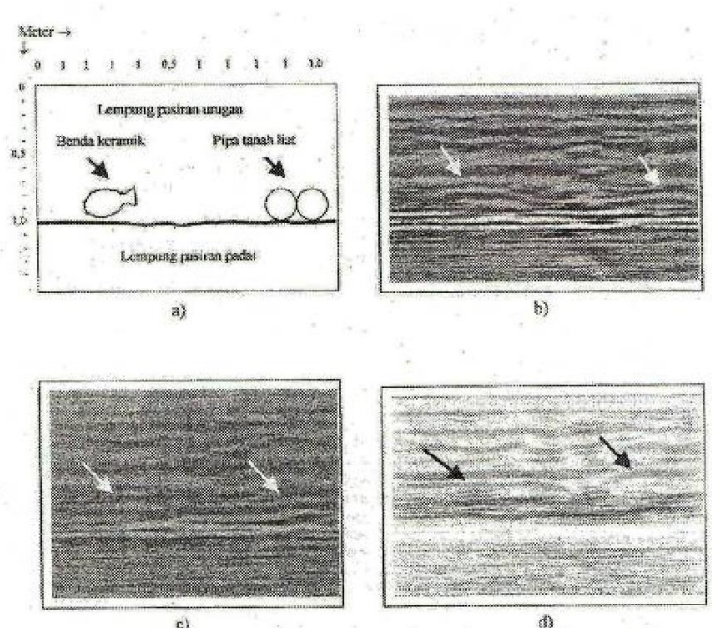

sumber: Untoro 1999:78-89

Gambar 14. Pemodelan obyek arkeologi dengan bahan dari tanah liat dan keramik.

(a) skema bentuk dan lokasi obyek; (b) citra georadar data lapangan; (c) citra georadar setelah dimigrasi; (d) citra georadar setelah didekonvolusi dan migrasi

Keterangan: Data lapangan diambil dengan filter frekuensi lolos rendah $1800 \mathrm{MHz}$ dan lolos tinggi $225 \mathrm{MHz}$. Proses migrasi menggunakan metode Kirchhoff dengan kecepatan relative 0,38 dan lebar hiperbola $63 \mathrm{scan}$. Proses dekonvolusi menggunakan parameter operator length 2,5 prediction lag 5 dan prewhitening $0,1 \%$.

Salah satu peralatan georadar yang saat ini banyak digunakan pada penelitian (misalnya guagua karst) adalah GPR Future Series 2005. Jenis peralatan ini mempunyai beberapa perbedaan dengan GPR konvensional pada umumnya, yaitu pada GPR Future Series 2005 pada antena terdiri dari beberapa receiver dan satu transmitter yang berada di tengah-tengah antena sehingga outputnya berupa kontur yang menggambarkan penampang horisontal dari zona penelitian. Pada GPR konvensional terdiri dari satu transmitter dan satu receiver dan outputnya, yaitu penampang vertikal yang berupa satu gelombang untuk setiap pengukuran. Dan pengukuran dilakukan berulangulang kemudian hasilnya digabungkan lalu dilakukan pengolahan data lanjutan (Syaeful dkk. 2009: 1-12).

Apabila GPR Future Series 2005 dibawa berjalan (menurut garis lurus), gambar yang dihasilkan akan membentuk pola-pola tertentu, bergantung kepada objek yang ditumbuk oleh impuls elektromagnetik itu dan waktu tempuh 


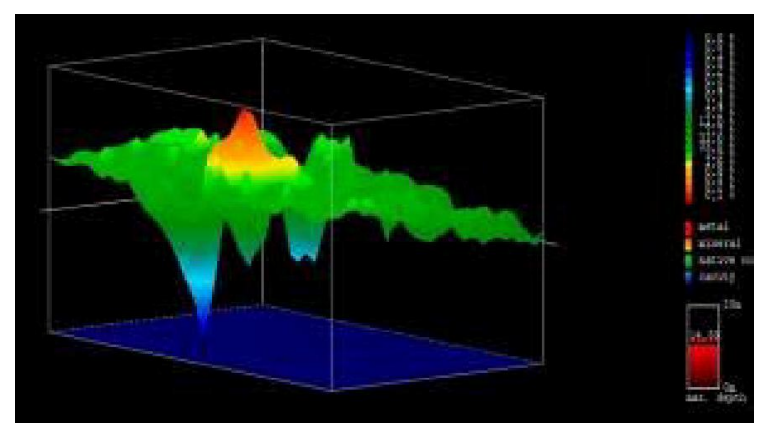

sumber: Syaeful dkk. 2009: 1-12

Gambar 15. Hasil olahan (output) dari GPR Future Series 2005, dalam bentuk tiga dimensi

sinyal (yang bergantung kepada kedalaman objek). Berikut ini adalah contoh gambar keluaran dari GPR Future Series 2005 beserta sedikit penjelasan tentang pola-pola gambar di dalamnya, yang disebut sebagai difraksi (Syaeful dkk. 2009:1-12). Sumbu horisontal adalah sampling impuls yang dipancarkan. Sumbu vertikal adalah jarak kedalaman atau waktu tempuh sinyal impuls dari pemancar ke penerima. GPR memiliki keterbatasan kehandalan operasi hanya sampai beberapa meter di bawah permukaan. Semakin konduktif objek yang ditumbuk, maka akan semakin jelas sinyal yang ditangkap. Kabel listrik adalah tembaga yang berkonduktivitas sangat baik, sehingga akan memberikan pola yang jelas pada gambar keluaran GPR. Pada contoh gambar tersebut ada anomali yang ditunjukkan oleh warna kuning yang menunjukkan adanya mineral di daerah tersebut. Anomali lainnya ditunjukkan oleh warna biru, yang menunjukkan daerah objek penelitian yang memiliki zona cavity atau zona kosong (lihat gambar 15) (Syaeful dkk. 2009: 112).

Penerapan Georadar dalam Penelitian Arkeologi Indonesia

Beberapa dekade lalu pemanfaatan teknologi telah dilakukan di dunia arkeologi Indonesia, yaitu pada tahun 1982, georadar telah dipergunakan dalam penelitian di Trowulan, yang dilaksanakan oleh Tim Geofisika ITB dan didampingi oleh Bapak Machi Suhadi (Puslit Arkenas). Awal 1990an Puslit Arkenas telah bekerjasama dengan John M. Stanley PhD. dari Lembaga Geophysical Research Institute (Australia) dalam penelitian
Kerajaan Sriwijaya di Palembang. Selain itu, penelitian geolistrik telah dilaksanakan di situs Batujaya, Karawang, Jawa Barat, situs Sriwijaya di Palembang, dan situs Muara Jambi di Jambi. Penelitian ini terlaksana atas kerjasama antara Bakosurtanal, Direktorat Sejarah dan Purbakala, Puslit Arkenas. Instansi lain, seperti Ditlinbinjarah telah memanfaatkan metode geofisika dalam penelitian-penelitian tinggalan kepurbakalaan yang bekerja sama dengan Bakosurtanal dan Institut Teknologi Bandung (Intan 1994: 1-36).

Selain penelitian tersebut, dalam beberapa kegiatan seminar arkeologi yang dilakukan oleh Puslit Arkenas, juga telah diperkenalkan metode geofisika dalam menunjang penelitian arkeologi, yaitu

1. Sarwono W. pada REHPA I (Cisarua, 8-13 Maret 1982), dengan makalahnya yang berjudul Penjajagan Magnetik.

2. Sartono S. pada AHPA IV (Kuningan, 10-16 September 1991), dengan makalahnya yang berjudul Pengaruh IImu Pengetahuan Alam PadaArkeologi.

3. Fadhlan S. Intan pada EHPA (Palembang, 1015 Oktober 1994), dengan makalahnya yang berjudul Peranan Geofisika Dalam Penelitian Arkeologi.

Sebenarnya, Puslit Arkenas telah memiliki sebuah peralatan geofisika, yaitu geomagnet. Spesifikasi dari peralatan tersebut adalah Proton Precession Magnetometer G-856. Namun, sejak penulis bergabung dengan Puslit Arkenas di tahun 1988, peralatan tersebut tidak dapat dipergunakan, karena sesuatu hal pada jaringan sumber listriknya (battery).

Seiring dengan perkembangan ilmu geofisika, maka pada dekade 1980-an, diperkenalkan sebuah metode baru dalam penelitian bawah permukaan, yaitu Ground Penetrating Radar (GPR) atau georadar.

Georadar telah dimanfaatkan dalam beberapa penelitian arkeologi di Indonesia, misalnya:

1. BPPT pernah menggunakan georadar untuk pendeteksi keberadaan situs purba di kota Pagar Alam di Desa Rimba Candi, Sumatera Selatan, yang terkubur akibat letusan Gunung Dempo. Situs itu merupakan peninggalan 
peradaban megalitikum (Hakim dkk. 2011: 1100).

2. Peneliti di Pusat Pengkajian dan Penerapan Teknologi Inventarisasi Sumber Daya Alam (TISDA) BPPT, Djoko Nugroho, mengungkapkan, aplikasi georadar telah dilakukan dalam pencarian bekas Kerajaan Sumbawa yang terpendam akibat letusan Gunung Tambora di Nusa Tenggara Barat. Pencarian yang melibatkan peneliti ITB ini berhasil menemukan lokasi situs kerajaan tersebut (Hakim dkk 2011: 1-100).

3. Dari kacamata sains dan teknologi, kerusakan sebagian dari situs Majapahit di Trowulan adalah akibat dari belum dikembangkannya ilmu geofisika pada bidang arkeologi. "Pemetaan arkeologi bawah tanah yang merupakan perpaduan antara geofisika dan arkeologi nyaris tak tersentuh di Indonesia, antara lain karena dianggap kurang mempunyai nilai ekonomis," ujar Anggoro Sri Widodo, geofisikawan lulusan S-2 ITB yang kini bergabung di CITIC Seram Energy. Di Indonesia, program studi geofisika terfokus pada bidang minyak dan gas bumi, eksplorasi mineral, geotermal, gempa dan tsunami, serta cuaca. Oleh karena adanya kesamaan teori, konsep, metode interpretasi antara geofisika migas dan geofisikaarkeologi, tidak sulit memetakan situs Majapahit di Trowulan yang telah terpendam. Akan tetapi yang membedakan adalah dalam eksplorasi migas digunakan energi gelombang getaran seismik untuk mendapatkan citra bawah permukaan, sedangkan untuk kepentingan pemetaan arkeologi digunakan sumber gelombang radar (Ground Penetration Radar/GPR) (Hakim dkk 2011: 1-100).

4. Pada hari terakhir proses ekskavasi tahap pertama candi di kompleks kampus Universitas Islam Indonesia (UII), Jalan Kaliurang km 14, Sleman, Tim Balai Pelestarian Cagar Budaya (BPCB) Yogyakarta berhasil membuat denah bangunan dengan jelas dan menemukan dua bangunan candi yang berhadap-hadapan.
Georadar digunakan untuk mengecek temuan di bawah tanah dengan anomali radar. Menurut Budhy Sancoyo (Arkeolog BPCB Yogyakarta), georadar digunakan untuk membantu mencari letak dan menemukan temuan-temuan benda lain yang masih terpendam tanah, sehingga mempermudah dan menghemat waktu pencarian bendabenda lain yang mendukung temuan candi. Selain itu, alat ini dapat mendeteksi kedalaman keberadaan benda sehingga memudahkan penggalian (Nurfiani 2010: 1-2)

5. Candi Prambanan yang terletak di perbatasan Provinsi DIY dan Jawa Tengah pascagempa bumi tampak mengalami kerusakan cukup parah. Di bagian halaman candi banyak batubatu candi (bagian ratna) berserakan akibat goncangan gempa, namun secara keseluruhan seolah-olah masih tegak berdiri dengan kokoh, dan kekawatiran akan adanya gempa susulan yang mungkin mengakibatkan bertambah parah kondisi sekarang ini. Selama ini masih sering terjadi gempa susulan di kawasan Yogyakarta dengan kekuatan gempa lebih kecil (Basah 2007: 594603). Untuk mengetahui kondisi tanah pendukung bangunan candi di kompleks Candi Prambanan dan struktur fondasinya perlu dilakukan uji geoteknik dengan melakukan pengeboran dan dikombinasi dengan uji geolistrik serta uji georadar, untuk mendapatkan informasi lebih mendalam tentang struktur bangunan bawah, serta karakteristik fisis maupun mekanis dari tanah dasar fondasinya (Basah 2007: 594-603).

6. Dalam pertemuan para ahli tingkat nasional pemugaran Candi Siwa Prambanan pada 3 Maret 2011 di Hotel Jayakarta, telah dipaparkan beberapa makalah yang terkait dengan pemugaran tersebut, antara lain, Ir. Suprapto mengemukakan Problematika Restorasi Struktur Candi Siwa, Dr. Ahmad Rifai menjelaskan tentang Kajian dan Pertimbangan Geoteknik Persiapan Pemugaran Candi Siwa, Daud Aris Tanudirjo memaparkan tentang Pemugaran Kembali Candi Siwa Pasca Gempa 2006 (Perspektif Arkeologis), dan Subagyo 
menjelaskan tentang Interpretasi Kerusakan Dinding Dalam Candi Siwa dengan Georadar (Joni 2011: 1-3)

7. Pada tahun 2011 Badan Geologi Kementerian Energi Dan Sumber Daya Mineral, telah melakukan penelitian dengan menggunakan metode georadar di Kompleks Percandian Muara Jambi (Tim Penelitian 2011: 1-35).

\section{PENUTUP}

Ground penetrating radar (GPR) atau georadar merupakan suatu alat yang digunakan untuk proses deteksi benda-benda yang terkubur di bawah tanah dengan tingkat kedalaman tertentu, dengan menggunakan gelombang radio. Metode georadar pertama digunakan ketika metode radar mula-mula dikembangkan. Beberapa lembaga penelitian di dalam dan di luar negeri membuat unit georadar dan perangkat lunak untuk memproses dan memvisualisasi data georadar. Peralatan georadar terdiri dari unit kontrol, antena pengirim dan antena penerima, penyimpan data dan peralatan displai. Aplikasi georadar dapat digunakan untuk survei benda-benda yang terpendam di tempat yang dangkal, tempat yang dalam, dan pemeriksaan beton.

Keuntungan penggunaan georadar adalah relatif mudah untuk dilakukan dan tidak merusak, dan antena tidak harus bersentuhan secara langsung dengan permukaan tanah. Keterbatasan utama georadar adalah lokasi capaiannya yang spesifik, dan antena georadar secara umum dioptimasi hanya untuk durasi pulsa tertentu.

Hasil eksperimen menunjukkan bahwa metode georadar mampu mencitrakan benda objek bawah permukaan dengan dimensi cukup sulit, seperti model geometri berongga, benda berdimensi kecil serta model bentuk sebaran keramik dan pipa tanah liat. Tes parameter pada proses dekomvolusi dan migrasi merupakan hal yang sangat penting dalam usaha meningkatkan kualitas citra. Koreksi elevasi harus dilakukan pada daerah yang berundulasi, agar diperoleh ketelitian yang lebih baik dalam kaitannya dengan estimasi kedalaman. Dengan kemampuan tersebut, maka metode georadar sangat bermanfaat dalam memecahkan permasalahan dalam dunia geologi, arkeologi, pertambangan, dan pemetaan benda-benda lainnya di bawah permukaan.

Pemanfaatan metode georadar dalam penelitian arkeologi di Inggris, Mesir, Jepang, Cina, Meksiko, India, dan beberapa negara di Amerika Selatan dan daratan Eropa lainnya, telah menghasilkan sukses besar dalam mengidentifikasi informasi dan menentukan lokasi objek arkeologi yang letaknya berada hanya beberapa meter sampai puluhan meter dari permukaan tanah. Kelebihan teknologi ini antara lain, biaya operasional lebih murah, resolusi yang sangat tinggi, pengoperasian mudah dan metode nondestruktif sehingga aman diaplikasikan.

Dua metode geofisika (geomagnet dan geolistrik), bukanlah hal yang baru di Puslit Arkenas, sedangkan georadar, Puslit Arkenas masih perlu mengembangkannya. Hal itu dapat diawali dengan kerjasama penelitian dengan perguruan tinggi, badan geologi, dan instansi lainnya serta perusahaan-perusahaan yang menggunakan georadar dalam pekerjaan rutinnya.

Sambil kerjasama penelitian tersebut berlangsung, Puslit Arkenas harus mengirimkan beberapa peneliti dan teknisi untuk mengikuti pelatihan-pelatihan yang mencakup penggunaan peralatan, dan interpretasi hasil pengukuran georadar. Setelah Puslit Arkenas memiliki tenagatenaga handal dalam penggunaan georadar, barulah dipikirkan untuk membeli peralatan tersebut.

Dengan peralatan yang lebih lengkap, diharapkan penelitian arkeologi yang dilaksanakan oleh Puslit Arkenas di masa mendatang akan lebih maksimal. 


\section{DAFTAR PUSTAKA}

Arisona. 2009. "Migrasi Data Dengan Metode Pergeseran Fasa". Jurnal Aplikasi Fisika 5 (1): 46-53. 2012. "Interprestasi Data Lapangan Ground Penetrating Radar (GPR) dengan Pemodelan Kedepan 2D". Jurnal Aplikasi Fisika 8 (1): 6-10.

Basah, Suryolelono Kabul. 2007. "Candi Prambanan Pasca Gempa Bumi”. Forum Teknik Sipil XVII (3): 594-603.

Budiono K., Handoko, Hernawan U., dan Godwin, 2010. "Penafsiran Struktur Geologi Bawah Permukaan di Kawasan Semburan Lumpur Sidoarjo, Berdasarkan Penampang Ground Penetrating Radar (GPR)". Jurnal Geologi Indonesia 5 (3): 187-195.

Deniyatno. 2011. "Identifikasi Zona Bidang Gelincir Tanah Longsor dengan Metode Georadar". Jurnal Aplikasi Fisika 7 (2): 69-76.

Drajat, Hari Untoro. 2003. "Metode Perekaman Data, Preserved by Record". HIm. 9399 dalam Cakrawala Arkeologi Persembahan Untuk Prof. Dr. Mundardjito. Depok: Jurusan Arkeologi, Fakultas Ilmu Pengetahuan Budaya, Universitas Indonesia.

Hakim, M. Agung, Alwi Sasmita K., Asri Wulandari,Bagus Hardiyansyah, Christian Sibuea, Fitri Wahyuningsih, Hardeka Pameramba, Lia Khairum T., Syamsul Ma'arif, Wilayan Pratama, dan Fernando Sialagan. 2011. Modul Eksplorasi Elektromagnetik. Lampung: Teknik Geofisika Universitas Lampung.

Intan, Fadhlan M. S. 1994. "Peranan Geofisika Dalam Penelitian Arkeologi". HIm. 136 dalam Evaluasi Hasil Penelitian Arkeologi (EHPA) Palembang, 10 - 15 Oktober 1994. Jakarta: Pusat Penelitian Arkeologi Nasional.
2001. "Arkeometri: Menapak Tebing Terjal Menuju Tahun 2002-2004". HIm. 111 dalam Evaluasi Hasil Penelitian Arkeologi (EHPA) Yogyakarta, Kaliurang, 18 - 21 September 2011. Jakarta: Pusat Penelitian Arkeologi Nasional. . 2013. "EHPA: Satu Kata Beribu Makna". HIm.1-11 dalam Evaluasi Hasil Penelitian Arkeologi (EHPA) Medan, 18 - 24 November 2013. Jakarta: Pusat Penelitian Arkeologi Nasional.

Joni. 2011. "Pertemuan Para Ahli Tingkat Nasional Pemugaran Candi Siwa Prambanan". Diunduh 9 Oktober 2011 (http:// ngarielmaya.blogspot.co.id/).

Jufri, Nurhikmah, Lantu, dan Muh. Altin Massinai (tanpa tahun). "Aplikasi Metode Ground Penetrating Radar (GPR) Untuk Identifikasi Seam Batubara". HIm. 1-9. Diunduh 12 Januari 2016 (http:// repository.unhas. ac.id/bitstream/ $\mathrm{h}$ a n d l e / 123456789 / 16636Jumal\%20Geofisika.pdf?sequence=1) Khumaidi, Fadhli dan Nazli Ismail. 2013. "Dimensionality Analysis of Magnetotelluric Data Crossing the Sumatran Fault System at Aceh Segment". Jurnal Natural 13 (2): 28-33.

Kuntjojo. 2009. "Metodologi Penelitian". Kediri: Universitas Nusantara PGRI Kediri. Diunduh 3 Maret 2016 (https:// ebekunt.files.wordpress.com/2009/04/ metodologi-penelitian.pdf)

Mundardjito. 1983. "Pengembangan Teknik Modern Untuk Arkeologi Indonesia". HIm 193-205 dalam Seminar Arkeologi, Cibulan, 2-6 Februari 1976. Jakarta: Pusat Penelitian Purbakala dan Peninggalan Nasional (P4N): Jakarta.

Nurfiani, Fira. 2010."Gunakan Georadar, Candi UII Terus Diungkap". Diunduh 21 Juni 2011 (http://www.krjogja.com/krjogja/news/

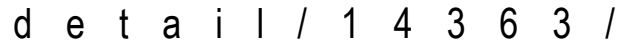


Gunakan. Georadar.Candi.UII. Terus.Diungkap.html).

Payne, Ian. 2013. "Identifying Sub Suarface Assets, Georadar Australia Pty". Diunduh 10 Februari 2016 (http:// georadar.net.au/locating/).

Reynold, John.M. 2011. An Introduction to Applied and Environmental Geophysics. John Willey \& Sons: New York

Said, Chaksana AH. 2003. "Analisis Fly-Ash: Sebuah Metode Identifikasi Fitur Dan Situs Zaman Industri. HIm. 41-58 dalam Cakrawala Arkeologi Persembahan Untuk Prof. Dr. Mundardjito. Depok: Jurusan Arkeologi, Fakultas IImu Pengetahuan Budaya, Universitas Indonesia.

Sartono, S. 1991. "Pengaruh IImu Pengetahuan Alam Pada Arkeologi". HIm. 1-14 dalam Analisis Hasil Penelitian Arkeologi (AHPA-IV) Kuningan, 10-16 September 1991. Jakarta: Pusat Penelitian Arkeologi Nasional.

Sarwono W. 1983. "Penjajagan Magnetik". HIm 521-532 dalam Rapat Evaluasi Hasil PenelitianArkeologi (REHPA-I) Cisarua, 8-13 Maret 1982. Jakarta: Pusat Penelitian Arkeologi Nasional.

Sedyawati, Edi. 1993. "Arah Kebijakan Pengembangan Kebudayaan Nasional dan Masa Depan Penelitian Arkeologi di Indonesia". HIm. 1-15 dalam Evaluasi Hasil Penelitian Arkeologi (EHPA) Yogyakarta, 26-30 Juli 1993. Jakarta: Pusat Penelitian Arkeologi Nasional.

Soejono, R.P. 1982. "Penelitian Arkeologi Di Indonesia Dan Masa Depannya". HIm 95-101 dalam Lokakarya Arkeologi, Yogyakarta, 21-26 Februari 1978. Jakarta: Pusat Penelitian Arkeologi Nasional.

.1990. "Arkeologi Di Indonesia In Volgenvucht". HIm 352-358 dalam "Monumen" Karya Persembahan Untuk Prof. Dr. R. Soekmono. Depok: Lembaran Sastra, Seri Penerbitan
IImiah No. 11 Edisi Khusus, Fak. Sastra Ul.

Syaeful, Bahri Ayi, Supriyanto, dan Sentosa Bagus Jaya. 2009. Penentuan Karakteristik Dinding Gua Seropan Gunung Kidul Dengan Metode Ground Penetrating Radar. Tesis. Surabaya: ITS. Diunduh 3 Maret 2016 (http://digilibits.ac.id/ public/ITS-Undergraduate-12481Paper.pdf)

Takahashi, Kazunori, Igel Jan, Preetz Holger, dan Kuroda Seiichiro. 2012. "Basics and Application of Ground- Penetrating Radar as a Tool for Monitoring Irrigation Process". Diunduh 10 Maret 2016 (http://cdn.intechopen.com/pdfs/ $\begin{array}{llllllllllll}3 & 1 & 5 & 0 & 1 & / & \mathrm{n} & \mathrm{n} & \mathrm{T} & \mathrm{c} & \mathrm{h}\end{array}$ Basics_and_application_of_ground penetrating_radar_as_a_tool for_monitoring_irrigation_process.pdf) Tim Penelitian. 2011. "Penelitian Bawah Tanah Terhadap Tinggalan Kepurbakalaan Di Kawasan Situs Percandian MuaroJambi Dengan Metode Ground Penetration Radar (GPR)". Diunduh 12 Januari $2016 \quad$ (https://idi d. f a c e b o o k. c o m / permalink.php?story_fbid=37856919554152 1\&id=145977939452)

Untoro, Priyono Awali. 1999. "Model Eksperimen Pengukuran Objek Bawah Permukaan Menggunakan Metoda Georadar". Jurnal Teknologi Mineral IV (2): 79-89

Yulius, Yudi, Yuyu Wahyu, dan Folin Oktafiani. 2008. "Studi Pemrosesan dan Visualisasi Data Ground Penetrating Radar". Jurnal Informatika LIPI 2 (1): 16.

Zulaikah, Siti., Era Prayekti B., Nugroho Pramono A., Yoyok Laksono A., Ninik Munfarikha, Rizka Amirul H., dan Husni Kurniawan C..2015. "Pengukuran Resistivitas Dan Dielektrisitas Tanah Perkebunan Apel: Sebuah Langkah Awal Dalam Studi Agrogeophysics". Spektra: Jurnal Fisika dan Aplikasinya. 16 (1): $52-54$. 